University for Business and Technology in Kosovo

UBT Knowledge Center

Nov 7th, 9:00 AM - 5:00 PM

\title{
The region of South Asia in International Relations - regional analysis approach
}

Jakub Zajaczkowski

University of Warsaw

Follow this and additional works at: https://knowledgecenter.ubt-uni.net/conference

Part of the Political Science Commons

\section{Recommended Citation}

Zajaczkowski, Jakub, "The region of South Asia in International Relations - regional analysis approach" (2015). UBT International Conference. 10.

https://knowledgecenter.ubt-uni.net/conference/2015/all-events/10

This Event is brought to you for free and open access by the Publication and Journals at UBT Knowledge Center. It has been accepted for inclusion in UBT International Conference by an authorized administrator of UBT Knowledge Center. For more information, please contact knowledge.center@ubt-uni.net. 


\title{
The region of South Asia in International Relations - regional analysis approach
}

\author{
Jakub Zajączkowski \\ Institute of International Relations, University of Warsaw
}

\begin{abstract}
The aim of paper is an attempt to provide a comprehensive and multidimensional presentation of the determinants that shape the South Asian region. The current state of research gives rise to the following research questions: What are the constitutive fact ors and values of South Asia? To what extent is the shape of the region of South Asia influenced by endogenous factors and to what extent by exogenous factors? What is the importance of South Asia for the new international order emerging in Asia? By answering these research questions, I have attempted to verify the following research hypothesis: The main constitutive factor of the region of South Asia are activities of major powers, both regional, such as India, and external, such as China and the United States. These powers perceive South Asia as key for the realisation of their superpower aspirations and as a means of increasing their own role in Asia.
\end{abstract}

Keywords: South Asia region, United States, China, endogenous factors, exogenous factors.

\section{Definition of the subject of the study: re gion of South Asia}

The region of South Asia consists of seven countries: India, Pakistan, Bhutan, Nepal, Sri Lanka, Bangladesh, and Maldives. It covers an area of 4.48 million square kilometres, which represents 10 per cent of the Asian continent and 2.4 per cent of the world's land area. The population of the region is more than 1.65 billion. South Asian countries form the South Asian Association for Regional Cooperation (SAARC). Some researchers and international organisations (e.g., the World Bank) define the region as including Afghanistan as well. In April 2007, Afghanistan became the eighth member of SAARC.

South Asia is a partly continental and partly sea region. It comprises sea areas that are part of the territories of coastal states or are subject to limited jurisdiction or sovereignty of the states in the region (mainly the exclusive economic zone). It is also important to mention areas outside the jurisdiction of states that are crossed by Sea Lanes of Communication (SLOCs). The region of South Asia therefore also covers: the Andaman Sea, the Bay of Bengal, the Arabian Sea, that is the areas that make up the northeastern and northwestern part of the Indian Ocean.

From a geographical point of view, South Asia is one of the regions of the Asian continent, the others being North Asia, Central Asia, East Asia, and West Asia.

Given the importance of South Asia in international relations, we can distinguish two periods: 1) until 1989 and 2) after the end of the Cold War. During the Cold War, South Asia was a peripheral region, but its importance has been gradually increasing since the end of the Cold War, as evidenced by the growing number of research and analyses on this subject.

Examining the role of the region of South Asia in international relations, we should stress that until the end of 1960s it was only seen in the context of the rivalry between India and Pakistan. The IndoPakistani conflict over Kashmir in fact reduced the importance of South Asia. Global superpowers, that is the Soviet Union and the United States, did not get directly engaged in the dispute. The peripheral character of South Asia was reflected by the geopolitical concept of S. B. Cohen.

The second phase during the Cold War was the period from the late 1960s to 1989. In this period, South Asia developed a two-bloc system: USSR-India (confirmed by a political-military alliance between New Delhi and Moscow in 1971) and US-China-Pakistan. This system, however, only consolidated the peripheral character of the region. The reasons for this were as follows: First, the major powers were interested in maintaining the status quo in South Asia. Moreover, they did not treat South Asia as an integral part of the security system of the Asia-Pacific region. Third, South 
Asia was marginal in the strategy of the Soviet Union and the United States. Fourth, the superpowers focused on competing in the Pacific and in East Asia; South Asia was not the area of their rivalry. Fifth, India, as the main country of the region of South Asia, did not play a key role on the Asian continent in security or economic terms; its foreign and security policy was restricted to the Indian sub-continent, partly because of the Pakistani and Chinese factors. India did not play the role of a major power in the Asia-Pacific region; it did not conduct effective and efficient policy in East Asia. Finally, in contrast to the countries of Southeast and East Asia, the economies of South Asia were not linked with each other and with other countries of East Asia by financial and trade ties.

The importance of South Asia in international relations considerably increased after the end of the Cold War. We should distinguish the following factors that had led to this increase:

- The rising role and position of India in international relations, which is evidenced by, for example, the strengthening of the relations with the United States, their more active and pragmatic regional strategy, based on the development of economic, political and strategic relations with the countries of South Asia, Southeast Asia and East Asia;

- A more active policy of China towards South Asian countries;

- The war in Afghanistan and the relations between Pakistan and Afghanistan; the intervention of the United States and other countries of the West in Afghanistan after 2001;

- India and Pakistan having achieved nuclear capability;

- The signing of the India-United States Civil Nuclear Agreement in 2006, which in fact meant that India was recognised as a nuclear power.

International relations in the region of South Asia are not just limited to the rivalry between India and Pakistan. They should also be perceived from the angle of the increasingly active strategies of China and the United States in the region as these determinants were a reason behind the modernisation of the armed forces of South Asian countries, mainly India. After 1989, the region of South Asia is becoming an important element in the new international order emerging in Asia. South Asia is no longer marginalised in international relations and in the study of international relations (As a bridge between the Indian Ocean and the Pacific, between West and East Asia, South Asia is becoming the key element in the new security architecture of Asia. Choosing this region as a subject of research is, therefore, by all means justified.

\section{Theory and methodology - the level of regional analysis in the study of South Asia}

The choice of the subject of research is related to the choice of the level of analysis in the study of international relations. The concept of levels of analysis was proposed in the 1950s and 1960s in American theory of international relations. The concept of levels of analy sis is a useful analy tical tool to organise, explain and understand the complex, interdependent international reality.

We can distinguish three main levels of analysis:

- State level (analy sis of international relations from the perspective of the state, its foreign policy; discussing the functioning of the state in an international environment);

- System level (analysis of international relations from the perspective of the international environment, that is the international system in which states operate);

- Regional level (analy sis of international relations from the perspective of subsystems, including regional subsystems).

The concept of levels of analy sis is therefore related to the dilemma of choosing the level of analysis, in particular of choosing the most adequate research perspective depending on the object of research. The emergence of the concept of the regional analy sis level in the 1960s was a response of researchers, especially those interested in non-European regionalism, to the concept of the state and system level analy sis. I point out that as a result of the growing importance of regional processes in non-European areas, some researchers attempted to objectify the procedure for distinguishing regions using quantitative and qualitative criteria in accordance with the requirements of system analy sis. They used the deductive method to apply the framework of Morton Kaplan's system approach for individual regions. Regions have become subsystems within the international system, each region characterised by local specificity related to certain cultural, social and historical factors. Regional subsystem analy sis was a response to the processes of decolonisation, to the emergence of new states in Asia and 
Africa; it allowed researchers to understand the mechanisms related with the regionalism of the countries of the South, whose main objective was to protect their newly gained independence.

In the concepts of regional analy sis, region is defined as a subordinate international system; a regional subsystem, an international subsystem, a subordinate system - an international region. The region is the level of analysis between the level of state and the international system. Just as the international system, it has its own structure, can be divided into further sub-regions. Region, or subsystem, is understood as a component of a larger system, characterised by distinct properties.

After choosing the level of regional analy sis (subsy stem analy sis), the researcher is faced with another dilemma - the choice of the method of regional analy sis that will be the most useful given the object of research. I discuss the traditional method of analysis of regions and regionalism and the new regional analysis in post-positivist approach.

Traditional regional analy ses refer to positivist principles. In analy sing individual regions, researchers refer to the geographical divisions of the political map. These concepts are essentially state-centric. The geographical factor and the role of the state are crucial for the study of international relations and for defining regionalism.

The end of the Cold War, the second wave of regionalism and the revitalisation of integration in Latin America and Asia have created conditions and reasons for the emergence of new approaches in regional analysis. Post-positivist concepts of regional analy sis rejected the thesis of state-centric and geographic character of regions. In the 1990s, some scholars, referring mainly to the principles of constructivism, began to present the level of regional analy sis using the approach of new regionalism. The Swedish researcher Björn Hettne proposed the concept of regionness, which is the main term of the new regionalism theory. I stress there that regionness highlights multidimensionality of the effects of regionalisation in specific geographic areas and therefore is a useful analytical tool for understanding the formation and consolidation of the region and its structure. The concept of regionness thus tries to describe the emergence of the region as a result of the processes of regionalisation. At the same time, I point out that there are in fact no natural regions in the concept of regionness. Regions are subject to change, they are constructed and deconstructed. The level of regionness may be different in each region.

Conducting the study of a given region at the level of regional analy sis, I emphasise the need to refer both to the positivist approaches (as the concept of regional security complex) and to post-positivist approaches. The traditional analy sis is an effective tool for study ing in particular the relations between countries in the region and the attitude of major powers to the region. Post-positivist concepts, in turn, make it possible to adequately examine the progress of regional integration and cooperation in the region by juxtaposing regional and national identity. The perception of regionness is in fact determined by the position of the region in terms of cohesion and identity. By studying the causes and extent of regionness, we can determine how the region evolves and how the way in which it is defined is consequently changing.

The main research tool in my research of the region of South Asia is, therefore, the theory and methodology of regional analysis in traditional and post-positivist approach.

Referring to the traditional concept of region by L. J. Cantori and S. L. Spiegel, according to which one region can have several cores, I propose to distinguish South Asia as an independent region in international relations because, in my opinion, South Asia can be considered one of the core regions of Asia. These assumptions are confirmed by Barry Buzan and Ole Wæver's regional security complex theory. The two scholars distinguish South Asia as one of the regional security complexes, a part of the Asian supercomplex.

Moreover, I stress that the traditional regional analysis, for example the concept of William R. Thompson, makes it possible to examine the interactions and elements constituting a region. $\mathrm{W}$. R. Thompson distinguishes the following attributes:

- A particular degree of regularity and intensity of interaction between the regional actors to the extent that a change at one point in the subsystem has an impact on the other points in the subsy stem;

- Geographical proximity;

- Internal and external observers and actors recognise the subsystem as a distinctive area or 'theatre of operation';

The subsystem consists of at least two and probably more actors.

The level of traditional regional analy sis is also useful in the study of the relations between India and its neighbours. For the traditional level of regional analysis highlights the fact that geographical 
proximity affects the patterns of friendship and enmity formed throughout history between the neighbours. Threats and cooperation are reflected to a greater extent on the regional than on the global scale. In the publications discussed herein I also refer to Thompson's and Buzan's theses of geographical proximity and interdependence as well as to Robert Jervis's security dilemma.

For a fuller understanding of South Asian regionalism we should, however, also refer to the postpositivist approach to regional analysis, for example to the concept of regionness. This approach, referring to historical, civilizational, cultural, and social determinants, seems to be extremely useful, especially in the context of the genetic aspect of South Asian regionalism that is ideas, concepts, etc.

\section{The Concept of South Asia as region in IR - genetic, operational, structural and functional dimensions}

Taking into account four dimensions: genetic, structural, operational and functional, indicates that the region of South Asia can be treated as a separate region in international relations. Using the criteria of regional-level analysis, we can assert that the region of South Asia has the following characteristics:

a) A certain degree of system-forming interdependences, with increasing intensity and regularity of these links;

b) It is perceived by internal and external actors as an important area of activity;

c) It undergoes dy namic changes in the process of mutual influences among the participants of the system and with other systems forming its environment (which concerns both the sea and land dimension in South Asia);

d) Specific system-forming relations that are unique for this region (the aspect of identity and culture, as exemplified by South Asian concepts of the state and of regional cooperation);

e) An increase in mutual interpenetration of the region of South Asia with other regional systems.

Above assumption explicitly confirms the research hypothesis that the main factor constituting the South Asian region are interactions among major powers, mainly India, the United States and China. These interactions have contributed significantly to the distinguishing and development of the regional system, which in turn entails qualitative and quantitative changes in its internal structures and in the international environment.

This is confirmed by the fact that the role and position of the region of South Asia in international relations has been gradually and steadily increasing since the end of the Cold War if we take into account the extent of involvement of major powers in the region and their regional strategies. My research shows that there are three powers that play a key role in the emancipation of South Asia. Their influence on intraregional relations is crucial, and South Asia plays different roles in the foreign policy strategies of each of them.

From India's point of view, the region of South Asia continues to be its own sphere of influence. It treats this area as a distinct geopolitical and geoeconomic region. After the end of the Cold War, however, India had to adjust the instruments and methods of its foreign policy in the region to the new conditions. Moreover, today India accepts the principle of balance of power in South Asia to a larger extent than before, especially as regards the role of the United States as a guarantor of security of Sea Lanes of Communication in the Bay of Bengal, the Arabian Sea and the Andaman Sea. This does not change, however, the Indian perception of South Asia. India still treats it as its main area of interest, with direct consequences for its security, prosperity and integrity.

For China, the region of South Asia is essential because it borders on the South China Sea area, which is a priority for the PRC. Therefore, the region of South Asia is perceived in the context of the Malacca Strait Dilemma. Despite the fact that South Asia is not part of the first or even the second island chain, its role in the Chinese strategy is systematically growing. The fact that at the beginning of the $21^{\text {st }}$ century China has been significantly evolving, redefining its role from a continental to a sea power, has created favourable conditions for the growing importance of South Asia, as has the departure in the Chinese maritime strategy from the geographical perception of the first and second island chain towards a more pragmatic and realist approach.

The United States, in turn, see the South Asian region in a wider context, namely in the context of maintaining US leadership in the Asia-Pacific region and in the Indian Ocean. South Asia is considered an important component of the new security architecture of Asia. This new approach of 
the United States to South Asia is confirmed by the significant evolution of its strategy towards the Indian subcontinent since the $1990 \mathrm{~s}$. The last decade of the $20^{\text {th }}$ century saw a normalisation of USIndia relations. However, the focus was mainly on economic issues. Political relations were still characterised by mistrust stemming from the differences between the US and India on the issues of Kashmir and the Indian nuclear program. It seems that only the Indian and Pakistani nuclear tests of 1998 and the war in Afghanistan made the Indian subcontinent one of the priority areas in the US policy in Asia, as reflected in the so-called 'US pivot to Asia'.

Studies on the strategies of India, China, and the United States have proven that regionalism plays a special role in the foreign policies of major powers, which adapt the methods and principles of their foreign policies to the special characteristics of each region. Their foreign policies towards individual regions are, in turn, a function of global policy, which is confirmed by the US strategy towards South Asia. On the other hand, the achievement of global objectives depends on the efficiency of regional policy, which is what India realised at the beginning of $21^{\text {st }}$ century.

My research shows that the process of emancipation of South Asia in international relations is also facilitated by the nature and type of intraregional interactions, which include: multilateral institutions, alliances, bilateral agreements, and trilateralism. In my research I argue that the most important thing for the emerging South Asian regional order is the trilateral sy stem: India-US-China, which has been developing since the beginning of the $21^{\text {st }}$ century. Interactions among these three powers occurring through mutual influences and interpenetration of their regional strategies contribute to the shaping, development and functioning of international relations in the South Asia region.

The trilateral system is complemented by smaller centres of influence, such as Pakistan and Afghanistan. A special role in this context is played also by Australia, Japan and the Southeast Asian countries. Although they do not influence the structure of South Asia directly, they exert significant indirect influence through alliances and by strengthening cooperation with countries in the region and with the United States and China, for example, by developing cooperation between India, the United States, Australia, and Japan under the so-called 'quadrilateral initiative'. Due to these circumstances, there is a natural demand for multilateral balance of power, as only this institution ensures stability and balance in the region. This is particularly important in South Asia, whose structure involves not only conflicting interests of major powers but also conflicts between small countries and one large state (geographically and economically). These structural determinants require continuous adaptation to the new and higher expectations and new initiatives. India's new regional policy after 1989 and its latest activity in 2014 show that New Delhi is aware that maintaining the Pax Indica on the Indian subcontinent using only military instruments is inefficient and in fact impossible. The new approach of India and other countries in the region to regionalism was favourable to the growth of regional interdependence that increases the vulnerability of all actors to the activity and influences from the regional system and from beyond it.

Regardless of revitalisation, the regional cooperation, is still significantly limited. As a result, the concept of balance of power is useful in explaining the interactions between countries in the region and the strategies of major powers. In the region of South Asia, there are in fact still no multilateral security institutions. This applies both to governmental and non-governmental forms of cooperation, especially in the field of security.

At the same time, my research has confirmed that the South Asian region has become an important part of the regional security system in Asia, as proven by: India's participation in East Asia summits and the development of cooperation between India and ASEAN, as well as the strengthening of relations with the United States, Jap an and Australia. Another factor that contributed to the increasing importance of South Asia is the growing role of the Indian Ocean region and of marine regionalism, which is reflected in the new concept of the Indo-Pacific sea region, under which South Asia is to play the central role.

The analy sis of the strategies of states in the South Asian region thus confirms that the functions of regionalism against the actors of the regional system manifest themselves in two ways. First, regionalism acts as a tool, a measure in the foreign policies of states. Second, however, the regional structures established by countries affect these countries as well, thus making them into subjects of regional influences.

To sum up my research on South Asia based on the criteria of the level of regional analy sis, I should emphasise that in South Asia we are dealing mainly with the dynamising and ordering function of regionalism. The dy namising function applies both to the participants and the international relations in general. In the case of the participants, this means that they take measures to adapt to the factors 
and stimuli stemming from the regional system, as exemplified not only by the evolving activity of India, China and the Unites States in the region but also by the actions taken by smaller countries of the South Asian region. As regards the function of dy namising international relations in general, it should be emphasised that the interactions taking place in the South Asian region contribute to the expansion of international relations in the objective, subjective and spatial aspects. The entirety of interactions in South Asia, which involve regulation, maintaining balance and ensuring identity, shapes the ordering function of regionalism in South Asia. This function is dynamic and innovative because it brings qualitatively new rules of conduct of state actors into international relations. It is affected not only by institutional conditions but even more by cultural, civilizational and identity factors as they have an impact on the formation of new practices, values, etc. It seems that a much smaller role is played by the forcing and integrating functions, which is due to the low level of institutionalisation of regional cooperation.

Taking into account the dynamics of interactions and interdependencies in the region of South Asia, there is the need to continue research on this subject. Further research should focus on the following research problems:

- $\quad$ The maritime strategies of major powers;

- The role of small states in the region of South Asia;

- The role of Afghanistan for the regional security system in the region of South Asia;

- The bandwagoning strategy in the implementation of foreign policies of small states in the region of South Asia and in the Indian foreign policy towards the United States.

\section{References}

1. B. Buzan, "South Asia Moving towards Transformation: Emergence of India as a Great Power", International Studies, 2002, no. 1.

2. B. Chakma, Pakistan's Nuclear Weapons, London and New York, 2009.

3. R. Hussein, Pakistan and the Emergence of Islamic Militancy in Afghanistan, London, 2005;

4. I.K. Gujral, "South Asia in the Family of Nations" in R. Thakur, O. Wiggen (ed.), South Asia in the World, Tokyo 2004, p. 23.

5. S.K. Mitra, "The Reluctant Hegemon: India's Self-Perception and the South Asian Strategic Environment", Contemporary South Asia, 2003, no. 3.

6. S.K. Mitra, "War and Peace in South Asia: a Revisionist View of India-Pakistan Relations", Contemporary South Asia, 2003, no. 3.

7. R. Wirsing, "Great-Power Foreign Policies in South Asia" in D.T. Hagerty (ed.), South Asia in World Politics, London 2005.

8. B. Karnad, "Minorities, Terrorism and Democratic Politics" in Current Domestic Policy Challenges and Prospects in South Asia: Collection of Papers Presented at a South Asian Regional Seminar Organised Jointly by the Institute of Regional Studies, Islamabad, and the Hanns Seidel Foundation, Islamabad, 2003.

9. I.N. Mukherjee, "Charting a Free Trade Area in South Asia: Instruments and Modalities", in T.N. Srinivasan (ed.), Trade, Finance and Investment in South Asia, New Delhi 2002, pp. 121 153.

10. For more, see P. Wignaraja, "Achieving Development with Equity”, South Asian Journal, 2007, no. 1 .

11. R.J. May, B. Ray (eds.), Corruption, Governance and Democracy in South Asia, Kolkata 2006.

12. R. Reddy (ed.), Dimensions of Crime and Corruption in India, New Delhi 2005.

13. K.C. Dash, Regionalism in South Asia. Negotiating cooperation, institutional structures, London-New York 2008.

14. V. Sury anaray an, "Plea for New Regional Organisation", South Asian Survey, 2002, no. 2.

15. P.R. Chari, P.I. Cheema, S.P. Cohen, Perceptions, Politics and Security in South Asia: The Compound Crisis of 1990, London-New York 2003.

16. N. Reed, "Regionalisation in South Asia: Theory and Praxis", Pacific Affairs, 1997, no. 2.

17. S.P. Cohen, India. Emerging Power, Washington 2001. 